\title{
Health Literacy among Women with Different Educational States in Baghdad
}

\author{
Zena Mudhafer Al-Nema*, Fadia Thamir Ahmed and Haydar Fakhri Al-Tukmagi \\ Department of Clinical Pharmacy, College of Pharmacy, University of Baghdad, Iraq; \\ zena_alnema@yahoo.com
}

\begin{abstract}
Health literacy is an important method used by the authorities to strengthen the health system. The aim of this study is to assess the knowledge of some basic health principles among women of different educational states. This is a crosssectional study, performed from December 2014 until January 2016, Baghdad. All candidates were: females > 18 years, neither medical staff nor students. They were divided into two groups: educated and uneducated. The sample included 213 women, there were 112 educated and 101 uneducated women. Regarding educated group, accurate answers regarding route of transmission of typhoid fever was $73.2 \%$ in educated subjects vs. $49.5 \%$ in uneducated subjects. Main source of information for both groups was personal experience, but internet was used more by educated 59 (52.7\%) whereas television by the uneducated 48 (47.5\%). In conclusion, educated women had better health literacy than uneducated. Pharmacists played an impotent role in health literacy in the uneducated. Activities of the Ministry of Health were influent on the educated women.
\end{abstract}

Keywords: Educated Women, Health Literacy, Health Information Sources

\section{Introduction}

Health literacy is a composite term to describe a range of outcomes to health education and communication, which are directed to improve health literacy ${ }^{1}$.

Health literacy is one of the important methods used by the health authorities to strengthen the health system, it is effective, simple and inexpensive; and remains the only method for enabling environment for health to thrive ${ }^{2}$.

The relation between bad literacy skills and health status is now better recognized and well understood. Understanding this relationship has led to the appearance of the concept of health literacy, this concept has two different roots-in clinical care and in public health ${ }^{3}$.

Improving health literacy means in addition to information transmission and skills for reading pamphlets; improving people's access to medical information and their ability to use it effectively, it is argued that developed healthliteracy is critical to empowerment. The implications for the content and tool of contemporary health literacy and communication are then considered. Emphasis is introduced to more personal forms of communication, and community-based educational outreach ${ }^{4}$.

Even in some developed countries (e.g., Switzerland) studies suggested that there is a dramatic lack of knowledge in the general public about the typical signs and risk factors of relevant clinical conditions ${ }^{5}$.

Although there are many methods which help in improving health literacy among the general population, of which the medical and pharmaceutical body forms the backbone, still the majority of researches reporting that inappropriate help was provided by pharmacy staff when handling self-medication needs in developing countries ${ }^{6}$.

In the era of information technology, many developing countries try very hard to move their health care system into the information age. Millions of people in Africa do not have any access to online sources to satisfy their need for enough individual health information ${ }^{7}$.

The objective of the present study is to assess the knowledge and familiarity with some basic health issues among women of different educational states, and to

${ }^{*}$ Author for correspondence 
evaluate different methods for enhancement of health literacy. This will help health authorities to make an effective use of the resources available in improving health literacy among Iraqi women and hence improving their children health.

\section{Methods}

A cross-sectional study was done from December 2014 until January 2016 in Baghdad city, capital of Iraq.

Sample was collected randomly from the Medical City in Baghdad, College of Pharmacy, school teachers, relatives and clinics.

Exclusion criteria were any women under 18 years old, and those who are medical staff or medical students.

The sample was divided into two groups:

Group A: educated (Candidates finished the secondary school and above).

Group B: uneducated (Candidates achieved primary school and less).

The candidates were interviewed by the researchers and certain points regarding the medical knowledge were explained and interrogated and the responds of the candidates were recorded as follows:

Accurate; if the response was similar or near to the medical truth.

Inaccurate; if it was different from the medical truth.

Don't know; if the candidate didn't know the answer.

The medical information tested included the following:

- Typhoid's signs and symptoms.

- Typhoid's causes.

- Typhoid's transmission.

- Viral hepatitis types.

- Viral hepatitis transmission.

- Cholera’s causes.

- Cholera's prevention.

- Cholera's transmission.

- Polio's transmission.

- Polio vaccination's age.

- Are antibiotics effective for influenza or common cold?

- Which is better a prescription containing one drug or another containing many drugs?

- Source of information or activities of the health institutes.

We chose these medical information to be tested believing that these health issues were among the most common medical problems facing the general population in Baghdad.

This questionnaire has been qualified by an expert committee in the College of Pharmacy of Baghdad University and they validated it.

This questionnaire was developed from a previous one which was tested on a small sample and to test its feasibility and reliability and modification done accordingly.

A comparison between the two groups regarding their health literacy and the source of information was made. The results were tabulated and statistical comparison were done between the two groups (A and $\mathrm{B}$ ) using Chi square. A p value $<0.05$ was considered significant.

\section{Results}

There were 213 women in this study. There were 112 educated (group A) and 101 uneducated (group B) women.

\subsection{Comparison of Educated vs. Uneducated Subjects Groups Medical Knowledge}

When we compare between the medical knowledge owned by educated subjects with that of uneducated subjects, (Table 1), it can be clearly seen that there was a significant difference in the medical knowledge between the two groups about the route of transmission of typhoid fever ( $p=0.003$, accurate answers: $73.2 \%$ in educated subjects vs. $49.5 \%$ in uneducated subjects), the route of transmission of polio ( $\mathrm{p}=0.006$, accurate answers: $19.6 \%$ vs. $6.9 \%$ in educated and uneducated subjects, respectively) and about the route of transmission of viral hepatitis ( $\mathrm{p}=0.01$, accurate answers: $56.3 \%$ in educated subjects vs. $28.7 \%$ in uneducated subjects).

On the other hand, there was a non significant difference in answers between the two groups (i.e., educated and uneducated subjects) regarding the types of viral hepatitis ( $\mathrm{p}=0.752$, accurate answers: $50.9 \%$ vs. $14.8 \%$ in educated and uneducated groups, respectively), the comparison between prescription with one item vs. one with many items ( $\mathrm{p}=0.797$, accurate answers: $72.3 \%$ in educated subjects vs. $70.3 \%$ in uneducated subjects).

While talking about the source of medical information possessed by the two groups, it was obvious that there was a significant difference in the medical knowledge gained by personal experience, internet, television, and the 
activities of the Iraqi Ministry of Health (posters, lectures, meetings or conferences). It also showed that there was a non significant difference in the medical information acquired by direct contact of the subjects with community pharmacies and community medicine experts or gained through listening to radio.

\section{Discussion}

On the basis of the responses to the 14-qeuestionquestionnaire in the survey, it was found that educated women were more aware of common medical problems (e.g., viral hepatitis, cholera, and polio) than the uneducated. This can be explained easily by the fact that educated women were in contact with medical information through their study or through attending scientific and public activities related to health problems.
Exception to this, knowledge of signs, symptoms and route of transmission of typhoid fever which was more in the uneducated group, this may be explained by the fact that this disease is endemic in lower socioeconomic and low educational sector of the society which gives them a personal experience of the presentation (which is related to signs and symptoms) and preventive measures (which is related to route of transmission). This fact was studied in Ghana revealed that mothers' duration of school education is strongly associated with health literacy ${ }^{8}$. The findings of another study done in Bangladesh showed that a low level of education on cholera among risky groups calls for supporting health education activities to increase their knowledge on cholera ${ }^{9}$, another study done on the old people in China revealed that candidates who finished high school or higher had 6, 4, and 3 times bigger odds of possessing adequate health literacy than those who

Table 1. Comparison of educated vs uneducated group medical knowledge

\begin{tabular}{|c|c|c|c|c|c|}
\hline \multirow[t]{3}{*}{ Questions } & \multicolumn{4}{|c|}{ Number of subjects answered (\%) } & \multirow[t]{3}{*}{ p-value } \\
\hline & \multicolumn{2}{|c|}{ Educated $(n=112)$} & \multicolumn{2}{|c|}{ Uneducated $(n=101)$} & \\
\hline & Accurate & Inaccurate & Accurate & Inaccurate & \\
\hline 1- Typhoid's signs and symptoms & $54(48.2 \%)$ & $57(50.9 \%)$ & $64(63.3 \%)$ & $33(32.7 \%)$ & $0.011^{\star}$ \\
\hline 2- Typhoid's causes & $42(37.5 \%)$ & $67(59.8 \%)$ & $29(28.7 \%)$ & $66(65.3 \%)$ & 0.231 \\
\hline 3- Typhoid's transmission & $82(73.2 \%)$ & $25(22.3 \%)$ & $50(49.5 \%)$ & $38(37.6 \%)$ & $0.003^{\star}$ \\
\hline 4- Viral hepatitis types & $57(50.9 \%)$ & $27(24.1 \%)$ & $15(14.8 \%)$ & $6(5.9 \%)$ & 0.752 \\
\hline 5- Viral hepatitis transmission & $63(56.3 \%)$ & $47(42 \%)$ & $29(28.7 \%)$ & $47(46.5 \%)$ & $0.010^{*}$ \\
\hline 6- Cholera's causes & $99(88.4 \%)$ & $0(0 \%)$ & $75(74.3 \%)$ & $4(3.9 \%)$ & $0.023^{*}$ \\
\hline 7- Cholera's prevention & $70(62.5 \%)$ & $41(36.6 \%)$ & $65(64.4 \%)$ & $31(30.7 \%)$ & 0.484 \\
\hline 8- Cholera's transmission & $75(67 \%)$ & $37(33 \%)$ & $54(53.5 \%)$ & $37(36.6 \%)$ & 0.261 \\
\hline 9- Polio's transmission & $22(19.6 \%)$ & $50(44.6 \%)$ & $7(6.9 \%)$ & $55(54.5 \%)$ & $0.006^{*}$ \\
\hline 10- Polio vaccination's age & $50(44.6 \%)$ & $58(51.8 \%)$ & $54(53.5 \%)$ & $43(42.6 \%)$ & 0.180 \\
\hline $\begin{array}{l}\text { 11-Are antibiotics effective for influenza or } \\
\text { common cold? }\end{array}$ & $49(43.8 \%)$ & $63(56.3 \%)$ & $59(58.4 \%)$ & $41(40.6 \%)$ & $0.026^{*}$ \\
\hline $\begin{array}{l}\text { 12-Which is better a prescription containing } \\
\text { one drug or another containing many drugs? }\end{array}$ & $81(72.3 \%)$ & $23(20.5 \%)$ & $71(70.3 \%)$ & $22(21.8 \%)$ & 0.797 \\
\hline
\end{tabular}

Table 2. Information source of the subjects (Q13 answers)

\begin{tabular}{lccc}
\hline Information source & $\begin{array}{c}\text { Educated }(\mathbf{n}=112) \\
\text { No. of subjects (\%) }\end{array}$ & $\begin{array}{c}\text { Uneducated (n=101) } \\
\text { No. of subjects (\%) }\end{array}$ & P-value \\
\hline 1-Personal experience & $65(58)$ & $73(72.3)$ & $0.029^{*}$ \\
2-Pharmacist education & $15(13.4)$ & $23(22.8)$ & 0.074 \\
3-Physician education & $26(23.2)$ & $34(33.7)$ & 0.090 \\
4-Internet & $59(52.7)$ & $18(17.8)$ & $<0.0001^{*}$ \\
5-Television & $37(33)$ & $48(47.5)$ & $0.031^{\star}$ \\
6-Radio & $13(11.6)$ & $7(6.9)$ & 0.242 \\
7-Ministry of Health activities & $55(49.1)$ & $28(27.7)$ & $0.001^{*}$ \\
\hline
\end{tabular}

* P-value $<0.05$ was considered significant. Many subjects have more than one source of information. 
attended below primary school, primary school, and junior high school levels, respectively ${ }^{10}$.

Unexpectedly, in the present study, the uneducated group was more alert to the fact that antibiotics are of no value in the treatment of common cold and influenza. This fact needs to be more investigated as there is a trend of the uneducated people to seek medical help from unauthorized public persons who prescribes usually herbal medicine. This result does not agree with a study done in rural Vietnam which found that most of the children had been administered antibiotics for common colds, although most medical staff believed that antibiotics were not needed. Antibiotics were abused at health facilities in the area ${ }^{11}$ and another study done in Taiwan which imply the need for programs to maintain greater education about antibiotics use in the general public of Taiwan ${ }^{12}$.

In the current study, personal experience was the main source of health information for the uneducated group and this can be explained easily in that such health problems were more common in the low social class and the effect of other sources of health information were less in these communities.

Also, TV was an important source of health information for the uneducated class due to the popularity of this type of media and the focused propaganda made through it during the epidemics of this disease as what happened in 2015 and this reflects the importance of this media in the release of medical information and alerts the health services for more effective use of this media in combating major health problems affecting the country. These results were similar to the results of a study done in $\mathrm{Haiti}^{13}$. And another study made in Shanghai which concluded that news media (87.1\%) was the most common source to acquire disaster medicine knowledge ${ }^{14}$.

In the present settings, the least source of information for the uneducated group was the radio.

While the educated group were using the more advanced tools like the internet which was a good source of information found in a study done in three Indonesian islands by ensures that there is a pivotal role for 'software' related interventions to encourage behavior change and generate demand for goods and services, alongside development of water and sanitation infrastructure ${ }^{15}$.

Educated people also attended and participated more in the scientific and cultural activities held by health authorities like the Ministry of Health and WHO. This should bring the attention of these authorities to improve their campaigns and direct them more to the uneducated and low social class of the society.

Personal experience followed by internet as the highest source of information in the educated group whereas radio ranked the lowest.

The effect of medical professionals (pharmacists and physicians) as a source of health information was more prominent in the uneducated group than in the educated one, this reflects the importance of this sector in providing health knowledge, this result agrees with a study done in Palestine found that community pharmacists' role is a major part to make a potential impact in ensuring that medicines are used correctly ${ }^{16}$.

Notably all of the educated group members were perfectly alert of the causes of cholera, this may be attributed to the strong campaign held by the health authorities against the disease. A study done in Cameroon, found that cholera affected 23,152 person and killed 843 in 2010 and there were participants who have good education of cholera ${ }^{17}$.

From the above, it is notable that health literacy is a multifactorial dependent problem (social, economic, cultural and educational levels) this is the same conclusion made by ${ }^{18}$ "Human health is a social matter, not just an individual one. A comprehensive approach to health promotion also requires changing the practices of social systems that have widespread effects on human health".

In conclusion: Educated women had a good knowledge on common medical problems but the uneducated showed overall limited health knowledge. Personal experience and TV were the main sources of information for the uneducated while personal experience followed by internet for educated women, respectively. Pharmacists and physicians' contact played an impotent role in health literacy in the uneducated women while the activities of the Ministry of Health were more influent on the educated women.

Recommendation: TV should be effectively used to improve the level of knowledge in the general population, especially the uneducated group. More oriented and fruitful usage of the internet will definitely improve the health literacy especially in young age group.

\section{References}

1. Ilona S Kickbusch. Health literacy: Addressing the health 
and education divide. Health Promote Int. 2001; 16(3): 28997.

2. Asaolu SO, Ofoezie IE. The role of health education and sanitation in the control of helminth infections. Acta Tropica. 2003; 86(2-3):283-94. https://doi.org/10.1016/S0001706X(03)00060-3

3. Nutbeam D. The evolving concept of health literacy. Social Scienceand Medicine.2008;67(12):2072-8.PMid:18952344. https://doi.org/10.1016/j.socscimed.2008.09.050

4. Nutbeam D. Health literacy as a public health goal: A challenge for contemporary health education and communication strategies into the 21st century. Health Promotion International. 2000; 15(3):259-67. https://doi.org/10.1093/ heapro/15.3.259

5. Bachmann LM, Gutzwiller FS, Puhan MA, Steurer J, Steurer-Stey C, Gigerenzer G. Do citizens have minimum medical knowledge? A survey. BMC Medicine. 2007; 5:14. PMid:17540024 PMCid:PMC1894984. https://doi. org/10.1186/1741-7015-5-14

6. Brata C, Gudka S, Schneider CR, Clifford RM. A review of the provision of appropriate advice by pharmacy staff for self-medication in developing countries. Res Social Adm Pharm. 2015; 11(2):136-53. PMid:25139059. https://doi. org/10.1016/j.sapharm.2014.07.003

7. Wiesner M, Pfeifer D. Building a widespread public health education system for developing countries in Africa. Stud Health Technol Inform. 2013; 190:240-2. PMid:23823435.

8. Greenaway ES, Leon J, Baker DP. Understanding the association between maternal education and use of health services in Ghana: Exploring the role of health knowledge. J Biosoc Sci. 2012; 44(6):733-47. PMid:22377424 PMCid:PMC3590019. https://doi.org/10.1017/S0021932012000041

9. Wahed T, Kaukab SST, Saha NC, Khan IA, Khanam F, Chowdhury F, et al. Knowledge of, attitudes toward, and preventive practices relating to cholera and oral cholera vaccine among urban high-risk groups: findings of a cross-sectional study in Dhaka, Bangladesh. BMC Public Health. 2013; 13:242. PMid:23509860 PMCid:PMC3608226. https://doi. org/10.1186/1471-2458-13-242

10. Yin Z, Geng G, Lan X, Zhang L, Wang S, Zang Y, Peng M. Status and determinants of health behavior knowledge among the elderly in China: A community-based cross-sectional study. BMC Public Health. 2013; 13:710. PMid:23915265
PMCid:PMC3751703. https://doi.org/10.1186/1471-2458$13-710$

11. Nguyen QH, Nguyen TK, Ho D, Larsson M, Eriksson B, Lundborg CS. Unnecessary antibiotic use for mild acute respiratory infections during 28-day follow-up of 823 children under five in rural Vietnam. Trans R Soc Trop Med Hyg. 2011; 105(11):628-36. PMid:21962293. https://doi. org/10.1016/j.trstmh.2011.07.015

12. Chen C, Chen YM, Hwang KL, Lin SJ, Yang CC, Tsay RW, Liu CE, Young TG. Behavior, attitudes and knowledge about antibiotic usage among residents of Changhua, Taiwan. J Microbiol Immunol Infect. 2005; 38(1):53-9. PMid:15692628.

13. De Rochars VEMB, Tipret J, Patrick M, Jacobson L, Barbour KE, Berendes D, et al. Knowledge, attitudes, and practices related to treatment and prevention of cholera, Haiti, 2010. Emerging Infectious Diseases. 2011; 17(11):2158-61.

14. Su T, Han X, Chen F, Du Y, Zhang H, Yin J, Tan X, Chang W, Ding Y, Han Y, Cao G. Knowledge levels and training needs of disaster medicine among health professionals, medical students, and local residents in Shanghai, China. PLoS One. 2013; 8(6):e67041. PMid:23826190 PMCid:PMC3691157. https://doi.org/10.1371/journal.pone.0067041

15. Alba S, Bakker MI, Hatta M, Scheelbeek PF, Dwiyanti R, Usman R, Sultan AR, Sabir M, Tandirogang N, Amir M et al. Risk factors of typhoid infection in the Indonesian Archipelago. PLoS One. 2016; 11(6):e0155286. PMid:27281311 PMCid:PMC4900629. https://doi.org/10.1371/journal. pone.0155286

16. Al-Ramahi R. Patterns and attitudes of self-medication practices and possible role of community pharmacists in Palestine. Int J Clin Pharmacol Ther. 2013; 51(7):562-7. PMid:23587151. https://doi.org/10.5414/CP201814

17. Nsagha DS, Atashili J, Fon PN, Tanue EA, Ayima CW, Kibu OD. Assessing the risk factors of cholera epidemic in the Buea Health District of Cameroon. BMC Public Health. 2015; 15:1128. PMid:26577770 PMCid:PMC4650512. https://doi.org/10.1186/s12889-015-2485-8

18. Bandura A. Health promotion by social cognitive means. Health Education and Behavior. 2004; 31(2):143-64. PMid:15090118. https://doi. org/10.1177/1090198104263660 